\title{
Ingredient modification to improve nutrition of Indonesian Koya made of nile and soy as a source of protein
}

\author{
1,* Anandito, R.B.K., ${ }^{2}$ Kawiji, ${ }^{3}$ Purnamayati, L. and ${ }^{4}$ Maghfira, L.L. \\ ${ }^{1}$ Department of Agricultural Product Technology, Vocational School, Universitas Sebelas Maret, Jl. Ir. \\ Sutami 36A, Surakarta 57126, Indonesia \\ ${ }^{2}$ Department of Food Science and Technology, Faculty of Agriculture, Universitas Sebelas Maret, Jl. Ir. \\ Sutami 36A, Surakarta 57126, Indonesia \\ ${ }^{3}$ Department of Fish Product Technology, Faculty of Fisheries and Marine Sciences, Universitas \\ Diponegoro, Jl. Prof. H. Soedarto, SH, Tembalang, Semarang 50275, Indonesia \\ ${ }^{4}$ Food Safety and Quality Engineering Program, Faculty of Agricultural, Food Sciences and \\ Environmental Management, University of Debrecen, Debrecen, Egyetem tér 1, 4032 Hungary
}

\begin{abstract}
Article history:
Received: 9 September 2020

Received in revised form: 18 October 2020

Accepted: 17 December 2020

Available Online: 11 April 2021
\end{abstract}

Keywords:

Koya,

Nile

Tilapia,

Protein,

Soy,

Tempeh

DOI:

https://doi.org/10.26656/fr.2017.5(2).498

\section{Introduction}

Indonesia is a maritime country, and its marine production is continuously rising from year to year. One of the marine products in Indonesia that keep increasing is Nile tilapia. Total production of Nile tilapia has increased from 914 tons in 2013 to 992 tons in 2015 (Sulistiyo, 2017). Its production continues to increase and able to encourage the level of public consumption. Besides its good tastes, tilapia also has a high nutritional content. Nile tilapia contains a high protein level of 14$18 \%$ and a low of fat 2-3\% (Desta et al., 2019). Protein on tilapia contains complete essential amino acids that are beneficial to health (Yarnpakdee et al., 2014). Tilapia is consumed by processing it into food products such as roll (Chambo et al., 2017) and fish nuggets (Lima et al., 2015). The high protein content in tilapia can be used as a source of protein in fast food such as Koya.

Koya is a native Indonesian food in the form of powder. Koya is usually added as a seasoning topping. Other seasoning toppings which commonly used are shredded, both shredded fish and meat, also coconut flakes which are used as a flavor enhancer. Koya is preferred because of its distinctive odor and savory taste, thus increasing appetite. Nowadays, the community put more attention to practical food with high nutrition for a healthy lifestyle (Ngozi et al., 2017). Fish koya is a pratical seasoning powder which high in nutrition. Regina et al. (2012) produced mackerel fish koya with 
protein $28.14 \%$, but the aroma was less preferred by panelists. Anandito et al. (2019) produced snakehead koya fish with the taste parameters were on neutral level for panelists. Snakehead fish production in Indonesia yet considered low and not a main commodities of freshwater fish (Indonesia Statistics, 2017). Therefore, koya fish from tilapia as main commodities of freshwater fish in Indonesia were developed due to the availability of raw material. Fish koya from tilapia presumably contains high nutrition particularly protein. Tilapia contains an amino acid, such as lysine and arginine that is beneficial for kids in the growth and development stage (Yarnpakdee et al., 2014; Uauy et al., 2015). Tilapia can be combined with vegetable protein sources such as soy. In order to increase its protein content, soy must contain unsaturated fatty acids and other nutritional content.

Soy has become a source of vegetable protein. Soy contains isoflavones that are beneficial to health, including reducing the risk of coronary heart disease and cancer (Messina, 2016). Soybean seeds contain 42\% protein, $19 \%$ fat, and $19 \%$ carbohydrates. Soybean processing cause changes in nutritional content. Soybeans processing can increase its protein content (Sharma et al., 2014). Soy in Indonesia has been processed into various products, such as tempeh, tofu, sweet soy sauce, tauco, and soy powder. Soy powder is also commonly used as a topping for native cuisine. The overripe tempeh also could be processed into seasoning powder (Gunawan-Puteri et al., 2015). The fermentation process can increase the protein content compared to unfermented soybean seeds. Bavia et al. (2012) stated that protein content in tempeh increase $41 \%$ compared to soybean seeds, while fat content in tempeh is not significantly different from soybean seeds. It depends on the variety used. Soybean has a good beany flavor (Ravi et al., 2019), which can cover the fishy smell from Nile tilapia; the combination of animal and vegetable protein is expected to produce complete nutrition content.

Recently, research on Koya is still rarely conducted. This seasoning topping is a typical Indonesian food that is very popular and liked. Koya can be used as an alternative to solve the problem of public malnutrition. The combination of tilapia and soy as a source of protein is expected to be able to produce healthy Koya and rich in protein. Besides, the combination of tilapia and tempeh in Koya was also examined. The aim of this study was to determine the characteristics of Koya made from tilapia combined with either soy or fermented soy (tempeh)

\section{Materials and methods}

\subsection{Materials}

The material used in this study was fresh red tilapia weighed $250 \mathrm{~g}$ per fish obtained from a local market in Surakarta, Central Java, Indonesia. Yellowish white soybean weighed $16-20$ g per 100 pieces obtained from soybean farmers in Grobogan, Central Java, Indonesia. While tempeh obtained from a Tempeh producer in Kampung Krajan, Mojosongo, Central Java, Indonesia. The tempeh used was 48 hours fermented soybean. Moreover, spices were used for making Koya (shallots, garlic, galangal, ginger, lemongrass, bay leaves, lime leaves, coriander, coconut milk, candlenut, palm sugar, salt, cooking oil, and "Sun Kara" instant coconut milk) and "2 Gajah" commercial Koya obtained from the local market in Surakarta, Central Java, Indonesia.

\subsection{Koya making}

The making of Koya was conducted based on Regina et al. (2012) with modifications. The spices showed in Table 1 were sautéed with cooking oil until fragrant. After the spices fragrant, instant coconut milk was added and heated until boiling. Ginger, galangal, lemongrass, bay leaves, lime leaves, palm sugar, and salt were added. Then steamed tilapia was added and stirred until homogeneous. Soybeans that have been floured was added and stirred until homogeneous and brownish. The Koya mixture then blended and sieved with a sixty-mesh sized sieve. For Koya made from tilapia and tempeh, Koya was made with the same steps, but the soy was replaced with tempeh that had been dried at $70^{\circ} \mathrm{C}$ for 6 hours then floured.

\subsection{Proximate analysis}

Proximate analysis including moisture, protein, fat, ash, and carbohydrate by difference (AOAC, 2005).

\subsection{Sensory analysis}

Sensory analysis was performed by a hedonic test using five scales consisting of 7: very likes, 6: likes, 5: somewhat likes, 4: neutral, 3: somewhat dislikes, 2: dislikes and 1: very dislikes. Hedonic tests were performed for color, taste, aroma, texture, and overall. The panelists were 40 untrained panelists (Huda et al., 2012).

\subsection{Amino acid profiles analysis}

The amino acid analysis was performed using HPLC (Shimadzu, Japan) with a C18 $4.6 \times 250 \mathrm{~mm}$ column. The eluent was methanol: acetate buffer $=80: 20$. The 5 $\mathrm{g}$ of sample was acid hydrolyzed with $20 \mathrm{~mL}$ of $6 \mathrm{~N} \mathrm{HCl}$ which had been vortexed then heated in an oven at $110^{\circ} \mathrm{C}$ 
Table 1. Formulation of Koya from Nile Tilapia and Soy (NS) and Nile Tilapia and Tempeh (NT)

\begin{tabular}{lccc}
\hline \multicolumn{1}{c}{ Materials } & NS1/NT1 & NS2/NT2 & NS3/NT3 \\
\hline Nile Tilapia (g) / (\%) (N) & $108(40 \%)$ & $135(50 \%)$ & $162(60 \%)$ \\
Soy (S) / tempeh flour (g) / (\%) (T) & $162(60 \%)$ & $135(50 \%)$ & $108(40 \%)$ \\
Garlic (g) & 55 & 55 & 55 \\
Shallot (g) & 40 & 40 & 40 \\
Candlenut (g) & 5 & 5 & 5 \\
Coriander (g) & 2 & 2 & 2 \\
Coconut milk (ml) & 200 & 200 & 200 \\
Ginger (g) & 3 & 3 & 3 \\
Galangal (g) & 6 & 6 & 6 \\
Lemongrass (g) & 8 & 8 & 8 \\
Bay leaves (sheet) & 2 & 2 & 2 \\
Orange leaves (sheet) & 4 & 4 & 4 \\
Palm sugar (g) & 25 & 25 & 25 \\
Salt (g) & 3 & 3 & 3 \\
\hline Total & 423 & 423 & 423 \\
\hline
\end{tabular}

NS1 (Nile: soybean 40:60); NS2 (Nile: soybean 50:50); NS3 (Nile: soybean 60:40); NT1 (Nile: tempeh 40:60); NT2 (Nile: tempeh 50:50) and NT3 (Nile: tempeh 60:40)

for $12 \mathrm{hrs}$. Heating was performed to accelerate the hydrolysis reaction and remove gases in the sample which able to interfere with the chromatogram result. The heated sample then cooled to room temperature, then neutralized with $6 \mathrm{~N} \mathrm{NaOH}$. After that, it was clarified with $5 \mathrm{~mL} \mathrm{~Pb}$-Acetate $40 \%$ and $2 \mathrm{~mL}$ of $15 \%$ oxalic acid then adjusted to $50 \mathrm{~mL}$ using distilled water. Approximately, $3 \mathrm{~mL}$ of the sample was taken then filtered with $0.45 \mu \mathrm{m}$ millex. Next, $20 \mu \mathrm{L}$ from the extraction result was taken and added $980 \mu \mathrm{L}$ of $0.1 \mathrm{~N}$ formic acid. Taking $50 \mu \mathrm{L}$ of sample to be added with $450 \mu \mathrm{L}$ of OPA solution, then vortex and reacted for 3 minutes. The last step was injecting $40 \mu \mathrm{L}$ into the HPLC. The separation of all amino acids until finished. The calculation of the amino acid concentration present in the material was done by making a standard chromatogram using ready-made amino acids that undergo the same treatment as the sample (AOAC, 2005).

\subsection{Fatty acid profiles analysis}

Fatty acid profile analysis was performed using gas chromatography (Shimadzu, Japan). The first stage was the extraction process using the Soxhlet method, then 20 $\mathrm{g}$ of fat was weighed in the form of oil. The next stage was the methylation process; this process aimed to form methyl ester, a fatty acid derivative compound. The methylation process was performed by refluxing the fatty acids on a water bath using the solvent $\mathrm{NaOH}$-methanol, isooctane, and $\mathrm{BF}_{3}$. Around $20 \mathrm{mg}$ of the sample was put into a test tube, and $1 \mathrm{~mL}$ of $0.5 \mathrm{~N} \mathrm{NaOH}$-methanol was added, then heated for 20 minutes, then the sample was cooled. The $2 \mathrm{~mL}$ of $20 \% \mathrm{BF}_{3}$ solution and $5 \mathrm{mg} / \mathrm{mL}$ of internal standard, then the sample was reheated for 20 minutes and cooled. The cooled mixture then added with $2 \mathrm{~mL}$ saturated $\mathrm{NaCl}$ and $1 \mathrm{~mL}$ isooctane, then the mixture was shaken carefully. The isooctane solution formed transferred into a tube which had been mixed with $0.1 \mathrm{~g}$ anhydrous $\mathrm{Na}_{2} \mathrm{SO}_{4}$ using a spotting pipette and left for 15 minutes, then an injection of $1 \mu \mathrm{L}$ FAME standard mixture (Supelco 37 component fatty acid methyl ester mix). Around $1 \mu \mathrm{L}$ sample was injected into Gas Chromatography (GC). The retention and peak time of each fatty acid was measured and compared with standard retention times (AOAC, 2005).

\subsection{Statistical Analysis}

This research was conducted in triplication. Data were analyzed using ANOVA. Then Duncan was performed as the post hoc test.

\section{Results and discussion}

\subsection{Chemical composition of raw materials}

The primary raw materials of Koya such as tilapia, soy, and tempeh were analyzed its chemical composition, including moisture, ash, fat, protein, and carbohydrate content. The results are presented in Table 2. The results showed that the highest composition on Nile tilapia was protein $15.97 \%$. Different results showed by Desta et al. (2019) tilapia $14.77 \%$ protein. It indicated that protein was the main content in tilapia the other raw ingredients such as soy and tempeh flour. Protein was also the highest component in soy and tempeh flour, $55.93 \%$ and $42.33 \%$; respectively. This result was higher compared to Uwem et al. (2017) the protein content in soy flour is $35.60 \%$, while Syida et al. (2018) indicated that tempeh flour contained $36.86 \%$ 
Table 2. Chemical Composition of Nile Tilapia, Soy, and Tempeh

\begin{tabular}{lccc}
\hline \multicolumn{1}{c}{ Parameters } & Nile Tilapia (Oreochromis niloticus) & Soy Flour & Tempeh flour \\
\hline Moisture (\%) & $80.01 \pm 0.04$ & $6.31 \pm 0.00$ & $4.76 \pm 0.24$ \\
Ash (\%) & $0.98 \pm 0.06$ & $4.60 \pm 0.00$ & $2.53 \pm 0.13$ \\
Fat (\%) & $0.51 \pm 0.11$ & $19.25 \pm 0.00$ & $22.93 \pm 0.35$ \\
Protein & $15.97 \pm 0.03$ & $55.93 \pm 0.02$ & $42.33 \pm 0.19$ \\
Carbohydrates by diff. (\%) & $2.45 \pm 0.05$ & $13.92 \pm 0.01$ & $27.15 \pm 0.28$ \\
\hline
\end{tabular}

Values are expressed as mean data (\% wet basis $) \pm$ standard deviation

protein.

\subsection{Chemical characteristics of Koya}

Examining the chemical characteristics of Koya aimed to determine the chemical content and the change in chemical composition during the processing. Instead of the three Koya formulas in the study, the proximate analysis was also performed on commercial Koya. It aimed to compare the nutritional value such as the proximate value of Koya from this study and the commercial one. The proximate analysis consisted of moisture, ash, fat, protein, and carbohydrate content. The results of the chemical analysis of Koya are presented in Table 3.

\subsubsection{Moisture}

Moisture content in ingredients could affect the quality of the food products. Dry products would decrease their quality if they contained high moisture content. Table 3 shows the moisture content of Koya NS ranged from $12.31-13.06 \%$ and NT ranged from 8.37$13.32 \%$, while the commercial was $8.70 \%$. The results by Huda et al. (2012) produces coconut flakes with moisture content ranging from $8-13 \%$.

The moisture content in Koya NS and NT increased along with the addition of Nile tilapia and soy flour or tempeh flour as the concentration decreased. Tilapia contained $80.01 \%$ of moisture which higher than soy and tempeh. The same result showed by Farzana and Mohajan (2015) that the addition of soy flour could reduce the moisture content in biscuits. It is due to the high levels of solids in soy compared to other ingredients in the formula. The solid content in tilapia, soy and tempeh flour (Table 2) showed that the solid content of tempeh flour and soy flour were higher compared to tilapia. Yulianti et al. (2019) stated that the addition of tempeh flour could reduce the moisture content of ingredients as indicated by a decrease in the moisture content of pasta with the addition of tempeh flour compare to control.

The moisture content of Koya NS and NT was higher than commercial Koya. It was because of the shrimp crackers which used as the raw materials in commercial Koya. The shrimp crackers frying process could reduce the moisture content, which was why the commercial Koya had a low moisture content. Zhang et al. (2015) stated that fried potato chips could be reduced their moisture content from $86 \%(\mathrm{wb})$ to $1.2 \%(\mathrm{wb})$. It occurred because the water in the material had evaporated due to temperatures that exceed the water boiling point during the frying process.

\subsubsection{Ash}

The concentration comparison of Nile tilapia-soy flour (NS) and Nile tilapia-tempeh (NT) affected the ash content of Koya. The ash content of Koya NS ranged from 4.88-5.15\% and Koya NT 2.68-3.89\%. Huda et al. (2012) the ash content of serunding was $4 \%$. The ash content of Koya NS and NT were higher than commercial Koya. This result is related to the soy ash content is greater than tempeh. The tempeh making process causes a decrease in ash (Bavia et al., 2012). Commercial Koya had the lowest ash content at $0.55 \%$. Its constituent materials influenced it.

\subsubsection{Fat}

According to Table 3, the fat content of Koya NS ranged between 19.59-21.70\% and Koya NT about 19.28 $-20.82 \%$. The higher the addition of tilapia and the lower the addition of soy or tempeh flour, the fat content on Koya decreased. Huda et al., (2012) produce shredded fish containing $18-31 \%$ fat. The fat content on Koya NS and NT were not different, and it was influenced by the fat content on its constituent ingredients, especially soy. During the fermentation process of soybeans into tempeh, the fat content did not change much as indicated by the results of fat content in soybeans and tempeh that were not significantly different (Bavia et al., 2012). When compared to the fat content in commercial Koya, the fat content of Koya NS and NT were lower. The fat content on commercial Koya was $30.06 \%$. It was because the raw material in commercial Koya was shrimp crackers. A frying process on shrimp crackers contributed to its fat content. During frying, the pores of the material will open due to water in the material that evaporates quickly. Cooking oil will enter the material from the open pores and replace the water (Zhang et al., 2015). 
Table 3. Chemical Characteristics of Koya

\begin{tabular}{cccccc}
\hline Sample & Moisture $(\%)$ & Ash $(\%)$ & Fat $(\%)$ & Protein $(\%)$ & Carbohydrates by diff. (\%) \\
\hline NS1 & $12.31 \pm 0.00^{\mathrm{a}}$ & $4.88 \pm 0.00^{\mathrm{a}}$ & $21.70 \pm 0.02^{\mathrm{c}}$ & $49.68 \pm 0.04^{\mathrm{a}}$ & $23.51 \pm 0.01^{\mathrm{c}}$ \\
NS2 & $12.44 \pm 0.01^{\mathrm{b}}$ & $5.08 \pm 0.00^{\mathrm{b}}$ & $20.65 \pm 0.01^{\mathrm{b}}$ & $51.25 \pm 0.00^{\mathrm{b}}$ & $22.89 \pm 0.01^{\mathrm{b}}$ \\
NS3 & $13.06 \pm 0.01^{\mathrm{c}}$ & $5.15 \pm 0.00^{\mathrm{c}}$ & $19.59 \pm 0.00^{\mathrm{a}}$ & $54.19 \pm 0.03^{\mathrm{c}}$ & $21.50 \pm 0.02^{\mathrm{a}}$ \\
\hline NT1 & $8.37 \pm 0.28^{\mathrm{a}}$ & $2.68 \pm 0.09^{\mathrm{a}}$ & $20.82 \pm 0.02^{\mathrm{c}}$ & $47.91 \pm 0.09^{\mathrm{a}}$ & $28.63 \pm 0.07^{\mathrm{b}}$ \\
NT2 & $12.03 \pm 0.14^{\mathrm{b}}$ & $2.97 \pm 0.18^{\mathrm{b}}$ & $20.43 \pm 0.09^{\mathrm{b}}$ & $48.30 \pm 0.15^{\mathrm{b}}$ & $28.43 \pm 0.22^{\mathrm{b}}$ \\
NT3 & $13.32 \pm 0.18^{\mathrm{c}}$ & $3.89 \pm 0.04^{\mathrm{c}}$ & $19.28 \pm 0.06^{\mathrm{a}}$ & $48.72 \pm 0.15^{\mathrm{c}}$ & $28.06 \pm 0.18^{\mathrm{a}}$ \\
\hline Commercial & $8.70 \pm 0.26$ & $0.55 \pm 0.02$ & $30.06 \pm 0.39$ & $6.88 \pm 0.14$ & $62.52 \pm 0.37$ \\
\hline
\end{tabular}

Values are expressed as mean \pm standard deviation. Values with different superscript within the column are significantly different $(\alpha=0.05)$.

NS1 (Nile: soybean 40:60); NS2 (Nile: soybean 50:50); NS3 (Nile: soybean 60:40); NT1 (Nile: tempeh 40:60); NT2 (Nile: tempeh 50:50) and NT3 (Nile: tempeh 60:40)

\subsubsection{Protein}

Protein in Koya NS ranged from 49.68-54.19\% and NT $47.91-48.72 \%$. Protein content in Koya was influenced by raw materials, supporting materials, and processing. The raw materials such as tilapia fillets content $15.97 \%$ protein in wet weight or equivalent to $79.97 \%$ in dry weight. The protein content of soy flour was $55.93 \%$ wet weight, or $59.70 \%$ dry weight and tempeh flour was $42.33 \%$ wet weight or equivalent to $44.54 \%$ dry weight. There was a process that will make the raw material drier. According to its dry weight, the protein content on tilapia fillets was higher than soy and tempeh flour, the more tilapia fillets added, the higher the protein content. The protein level of Koya in this study was higher than the shredded fish, around $27-28 \%$ (Huda et al., 2012). Koya NS and NT were high in protein. It showed that the constituent ingredients (tilapia, soy, and tempeh) contributed to the high levels of protein in Koya.

Table 3 shows that Koya NS and NT Koya had much higher protein content than commercial Koya made from shrimp and garlic crackers. Commercial Koya contained $6.88 \%$ protein. Raw materials and processing process could be the factors of lower protein in commercial Koya. The frying process can denature proteins in ingredients. Protein denaturation can occur because of the processing, especially with heat treatment.

\subsubsection{Carbohydrates}

The carbohydrate levels are analyzed using rough calculations or called carbohydrate by difference. The carbohydrate levels calculated by difference were influenced by other nutritional components, such as moisture, ash, protein, and fat content. The lower the other nutritional components, the higher the carbohydrate content and vice versa. Carbohydrate Koya NS ranged from $21.50-23.51 \%$ and NT $28.06-28.63 \%$. The more tilapia fillets added, the lower the carbohydrate content. It was because the raw material of Koya, the tilapia fillets had lower carbohydrate content compared to soy and tempeh flour. These results by Chambo et al. (2017) the carbohydrates in roll decreases with the increasing of tilapia concentration.

The commercial Koya had a much higher carbohydrate content than Koya NS and NT, around $62.52 \%$. According to Nguyen et al. (2013), the primary ingredient of shrimp crackers is tapioca flour. Tapioca flour contains starch, and it has a high carbohydrate content. The high levels of carbohydrates in shrimp crackers produce Koya with high carbohydrate levels.

\subsection{Organoleptic characteristics of Koya}

Koya was analyzed using sensory tests to determine the level of panelist preference on the color, aroma, taste, texture, and overall. The results of the sensory analysis are presented in Table 4.

\subsubsection{Color}

Table 4 shows that the Koya NS and NT in the colour parameters had a significant effect on each formula. Colour had an essential role because it could attract the characteristics of Koya. In this preference test, Koya NS1 and NT3 were the most preferred by panelist with values of 5.35 and 5.83. It showed that NS1 and NT3 were the best in color. Koya NS1 was light brown, and NT3 was a slightly darker brown. The brown color was the result of a Maillard reaction that occurred during processing. Maillard reaction is a non-enzymatic browning reaction between reducing sugars and amino acids during the heating process. This reaction produces Maillard Reaction Products that gives a brown colour to the product. The difference of brown colour in Koya NS1 and NT3 were influenced by the availability of amino acids and reducing sugars in the ingredients. Rannou et al. (2016) stated that the Maillard speed reaction was influenced by several factors, such as the reactant concentration, in this case, reducing sugars and amino acids. Tempeh in Koya NT3 produced a slightly darker 
Table 4. Organoleptic Characteristics of Koya

\begin{tabular}{cccccc}
\hline \multirow{2}{*}{ Sample } & \multicolumn{5}{c}{ Parameters } \\
\cline { 2 - 6 } & Color & Aroma & Taste & Texture & Overall \\
\hline NS1 & $5.35 \pm 1.05^{\mathrm{c}}$ & $4.40 \pm 1.46^{\mathrm{a}}$ & $3.80 \pm 1.31^{\mathrm{a}}$ & $5.95 \pm 1.26^{\mathrm{c}}$ & $3.63 \pm 1.51^{\mathrm{a}}$ \\
NS2 & $4.45 \pm 1.43^{\mathrm{b}}$ & $5.30 \pm 1.07^{\mathrm{b}}$ & $4.40 \pm 1.01^{\mathrm{b}}$ & $4.83 \pm 1.26^{\mathrm{b}}$ & $4.58 \pm 1.22^{\mathrm{b}}$ \\
NS3 & $3.38 \pm 1.63^{\mathrm{a}}$ & $6.00 \pm 0.88^{\mathrm{c}}$ & $5.45 \pm 1.28^{\mathrm{c}}$ & $4.13 \pm 1.81^{\mathrm{a}}$ & $5.38 \pm 0.91^{\mathrm{c}}$ \\
\hline NT1 & $4.48 \pm 1.09^{\mathrm{a}}$ & $4.35 \pm 0.95^{\mathrm{a}}$ & $4.35 \pm 1.01^{\mathrm{a}}$ & $5.30 \pm 0.91^{\mathrm{c}}$ & $4.23 \pm 0.77^{\mathrm{a}}$ \\
NT2 & $5.03 \pm 1.03^{\mathrm{b}}$ & $4.88 \pm 1.14^{\mathrm{b}}$ & $5.00 \pm 0.88^{\mathrm{b}}$ & $4.63 \pm 0.90^{\mathrm{b}}$ & $4.65 \pm 0.77^{\mathrm{b}}$ \\
NT3 & $5.83 \pm 0.81^{\mathrm{c}}$ & $5.60 \pm 0.91^{\mathrm{c}}$ & $5.58 \pm 0.91^{\mathrm{c}}$ & $4.08 \pm 0.97^{\mathrm{a}}$ & $5.13 \pm 0.97^{\mathrm{c}}$ \\
\hline
\end{tabular}

Values are expressed as mean \pm standard deviation. Values with different superscript within the column are significantly different $(\alpha=0.05)$.

NS1 (Nile: soybean 40:60); NS2 (Nile: soybean 50:50); NS3 (Nile: soybean 60:40); NT1 (Nile: tempeh 40:60); NT2 (Nile: tempeh 50:50) and NT3 (Nile: tempeh 60:40)

brown colour. The amino acid content in tempeh was higher than soy due to the fermentation process. Bujang and Taib (2014) stated that the amino acid in tempeh is higher than soybeans by 24 hours fermentation process. Fish koya from this study was better than Regina et al. (2012) which produced a darker appearance. This was due to the natural color of mackerel fish.

\subsubsection{Aroma}

Sensory analysis of the aroma parameters showed that panelists could accept Koya with a neutral to the like range. Koya NS3 and NT3 were the most preferred by panelists with scores of 6.00 and 5.60, respectively. Based on the aroma value, the Koya with the most addition of tilapia $60 \%$, was the most preferred by the panelist. The aroma that arose from the Koya NS and NT were the fragrant aroma from the combination of spices, tilapia, soy (NS), and tempeh (NT). The more tilapia added, the stronger the fish smell. Pratama et al. (2018) stated that the volatile component in tilapia comes from the hydrocarbon, alcohol, aldehyde, and ketone groups. The volatile component was detected due to environmental influences, like the processing process. Chukeatirote et al. (2017) stated that the main aroma components in soybean are alcohol, acids and esters, ketones, aldehydes, and furans. Tempe contains nineteen compounds that form its distinctive aroma and increases significantly to twenty-one aroma-forming compounds when tempeh fried. The main volatile compounds come from aldehydes and ketones, hydrocarbons, mono and sesquiterpenes, sulfur-containing compounds, nitrogencontaining compounds, alcohol, and furan (Jelen et al., 2013).

Ginger, galangal, bay leaves, garlic, shallot, lime leaves, and lemongrass was added as the spices. There was also the aroma of coconut milk and palm sugar. The aroma came out due to the presence of volatile substances in the spice. Spices contain volatile essential oils. These volatile compounds are responsible for the aroma formation in Koya. During the process, heat energy destructs the spice cell wall and the release of volatile compounds (An et al., 2015). According to Rannou et al. (2016), Maillard reactions that occur during Koya processing also play a role in the formation of aromas. During the Maillard reaction, an intermediate compound like the dehydro-reductor from sugar dehydration and fission products (volatile compounds 2,3-butadiene, 2,3-pentadiene or volatile precursors) from sugar fragmentation causes aldehyde formation through Strecker degradation. This aldehyde plays a role in flavor formation. This result was better than Regina et al. (2012) with mackerel fish koya aroma that was less preferred by panelists. This was due to the strong fishy odour of seafood than freshwater fish.

\subsubsection{Taste}

Based on the taste parameters, the Koya can be accepted by panelists with a somewhat dislike to like range. Koya NS3 and NT3 were the most preferred by panelists with scores of 5.45 and 5.58, respectively. The higher the tilapia added, the more preferred by panelists. Koya had a savory taste derived from the combination of tilapia, tempeh or soy flour, and seasonings. Tilapia contributes a savory taste to Koya fish because it contains glutamic acid. Yarnpakdee et al., (2014) showed that protein hydrolysate on tilapia contains dominant amino acids like glutamate acid, lysine, and aspartate acid. Soy flour has beany, greasy, pointy and bitter flavors, so it is less preferred (Damodaran and Arora, 2013), while raw tempeh which modified with the addition of $2 \%$ S. cerevisiae has a dominant taste of astringent, bitter, savory, and sour (Kustyawati et al., 2017). It was the reason why Koya with the highest percentage of tilapia was the most preferred. The taste parameter of koya in this study was better than Anandito et al. (2019), which on neutral level for high concentration of snakehead fish koya preferred by panelists. 


\subsubsection{Texture}

Texture analysis showed that panelists could accept Koya with a neutral to the like range. Koya NS1 and NT1 were the most preferred by panelists with scores of 5.45 and 5.58, respectively. It showed that the amount of tilapia added gave different texture value. These results by Cortez Netto et al. (2014), the amount of tilapia produces different texture values. The higher the tilapia added, the texture value decreased. Koya NS1 and NT1 had a rough and dry texture. It was also related to its moisture content. Koya NS1 and NT1 had the lowest moisture content among all sample. Low moisture content resulting in a dry texture.

\subsubsection{Overall}

Overall testing was intended to determine the panelist acceptance level, including color, aroma, taste, and texture. The overall parameters could be a whole, which panelists preferred the most. Table 4 shows that the composition of tilapia and soy or tempeh flour was significantly different against the overall value. The preference of Koya NS ranged from somewhat disliked to somewhat like, while Koya NT got neutral to somewhat like range. Koya NS3 and NT3 were the most favored by panelists with a value of 5.38 and 5.13, respectively.

\subsection{Fatty acids and amino acids profile}

Koya NS3 and NT3 as the most preferred by panelist were tested for fatty acid and amino acid profiles. The results are presented in Tables 5 and 6 .

Table 5 shows that Koya NS and NT contained eleven types of fatty acids that had been successfully identified. These fatty acids were divided into three types based on their chemical structure. The first category was saturated fatty acids (SFA), including caprylic acid, capric acid, lauric acid, myristic acid, palmitic acid, stearic acid, and arachidic acid. While monounsaturated fatty acids (MUFA) in Koya were palmitoleic acid and oleic acid, the polyunsaturated fatty acids (PUFA) in Koya were linoleic acid and linolenic acid.

The fatty acids in Koya fish came from the primary and supporting ingredients. Nile tilapia contains saturated fatty acids (caprylic acid, capric acid, lauric acid, heptadecanoic acid, myristic acid, palmitic acid, stearic acid, arachidic acid, and behenic acid), and unsaturated fatty acids (myristoleic acid, palmitoleic acid, oleic acid, linoleic acid, arachidonic acid, erucic acid, arachidonic acid, and $\alpha$-linolenic acid) (Navarro et al., 2012). The fatty acid in soy and tempeh flour consists of palmitic acid, stearic acid, oleic acid, linoleic acid, and eicosanoic acid (Kanghae et al., 2017). The saturated fatty acids (SFA) in commercial Koya was higher than NS3 and NT3 with a value of $42.13 \%$. The identified saturated fatty acids consist of seven fatty acids. The most SFA found in commercial Koya was palmitic acid. Saturated fatty acids in Koya NS3 and NT3 were dominated by lauric acid, about $15.49 \%$ and $15.86 \%$, respectively. The addition of coconut milk caused high lauric acid. Coconut milk is a coconut oil source, with $38.40 \%$ of lauric acid (Azevedo et al., 2020). Lauric acid in Koya also came from tilapia. Chen et al. (2013) stated that lauric acid is one of the fatty acids in tilapia was $1.41 \%$. Lauric acid is beneficial for the human body. Shah and Limketkai (2017) stated that lauric acid is a medium fatty acid easily absorbed by the digestion system. Also, it is the potential to reduce obesity and neurological disorders.

Table 5 shows that palmitoleic and oleic fatty acids were monounsaturated fatty acids (MUFA) found in

\begin{tabular}{|c|c|c|c|c|}
\hline No & Fatty acid & NS3 & NT3 & Commercial \\
\hline 1 & Caprylic acid (C8:0) & 2.29 & 2.39 & 0.03 \\
\hline 2 & Capric Acid (C10:0) & 1.78 & 1.93 & 0.03 \\
\hline 3 & Lauric acid (C12:0) & 15.49 & 15.86 & 0.24 \\
\hline 4 & Myristic acid (C14:0) & 6.08 & 5.57 & 0.87 \\
\hline 5 & Palmitic acid (C16:0) & 10.81 & 9.75 & 37 \\
\hline 6 & Stearic acid (C18:0) & 2.43 & 3.37 & 3.84 \\
\hline \multirow[t]{2}{*}{7} & Arachidic Acid (C20:0) & 0.27 & 0.17 & 0.12 \\
\hline & Total SFA & 39.15 & 39.04 & 42.13 \\
\hline 8 & Palmitoleic acid (C16:1) & 0.91 & 0.82 & 0.21 \\
\hline \multirow[t]{2}{*}{9} & Oleic Acid (C18:1) & 21.82 & 14.96 & 42.87 \\
\hline & Total MUFA & 22.73 & 15.78 & 43.08 \\
\hline 10 & Linoleic acid (C18:2) & 20.51 & 27.9 & 10.98 \\
\hline & Linolenic acid (C18:3) & 3.57 & 3.68 & 0.18 \\
\hline & Total PUFA & 24.08 & 31.58 & 11.16 \\
\hline
\end{tabular}

NS3 (Nile: soybean 60:40) and NT3 (Nile: tempeh 60:40) 
Table 6. Amino Acids Profile

\begin{tabular}{|c|c|c|c|c|}
\hline No & Amino acids & NS3 & NT3 & Commercial \\
\hline \multicolumn{5}{|c|}{ Non-essential amino acids } \\
\hline 1 & L-Alanine & 1.2 & 1.23 & 0.74 \\
\hline 2 & L-Arginine & 0.7 & 1.08 & 0.52 \\
\hline 3 & L-asparagine & 0.02 & $<0.01 \%$ & 0.09 \\
\hline 4 & L-aspartic acid & 1.37 & 1.6 & 1.31 \\
\hline 5 & L-glutamate acid & 2.17 & 2.38 & 2.23 \\
\hline 6 & L-Glutamine & $<0.01$ & $<0.01 \%$ & $<0.01 \%$ \\
\hline 7 & L-Glycine & 1.35 & 1.74 & 0.74 \\
\hline \multirow[t]{2}{*}{8} & L-Tyrosine & 0.47 & 0.74 & 0.26 \\
\hline & Total Non-essential amino acids & 7.28 & 8.77 & 5.89 \\
\hline \multicolumn{5}{|c|}{ Essential amino acids } \\
\hline 1 & L-histidine + L-serine & 1.17 & 3.61 & 1.14 \\
\hline 2 & L-Isoleucine & 0.6 & 1.03 & 0.5 \\
\hline 3 & L-Leucine & 1.12 & 1.77 & 0.97 \\
\hline 4 & L-Lysine & 1.37 & 0.61 & 1.14 \\
\hline 5 & L-Phenylalanine & 0.67 & 1.08 & 0.59 \\
\hline 6 & L-Threonine & 1.27 & 1.79 & 0.92 \\
\hline 7 & L-Tryptophan + L-Methionine & 0.6 & 0.32 & 0.16 \\
\hline \multirow[t]{2}{*}{8} & L-Valin & 0.72 & 1.42 & 0.59 \\
\hline & Total Essential amino acids & 7.52 & 11.63 & 6.01 \\
\hline
\end{tabular}

Koya NS3, NT3, and commercial. Palmitoleic and oleic in Koya F3 were from tilapia, soy, and tempeh flour. According to Navarro et al. (2012), tilapia contains palmitoleic and oleic acid. Kanghae et al. (2017), soy and tempeh contain high amounts of oleic acid. Compared to commercial Koya, Koya NS3 and NT3 Koya had higher levels of polyunsaturated fatty acids (PUFA). The total PUFA in the Koya NS3 and NT3 was $24.08 \%$ and $31.58 \%$, respectively while in the commercial Koya was $11.16 \%$. The identified PUFA in NS3, NT3, and commercial Koya were linoleic acid and linolenic acid. Linoleic acid could reduce the risk of cardiovascular symptoms (Marangoni et al., 2020). Linolenic fatty acids can be precursors of other omega-3 fatty acids such as eicosapentaenoic acid (EPA) and docosahexaenoic acid (DHA). In contrast to arachidonic acid (ARA) which formed proinflammatory eicosanoids, EPA and DHA formed anti-inflammatory eicosanoids. Linolenic fatty acids help resolve the inflammation and alter the vascular biomarkers and carcinogens function, moreover, reducing the risk of cancer and providing substantial protection against other chronic and metabolic diseases such as diabetes, obesity, osteoporosis, neurological degeneration, and fractures (Saini and Keum, 2018). Based on this research, NS3 and NT3 are beneficial in terms of fatty acid content compared to commercial Koya.

The amino acid in Koya NT3 came from its constituent ingredients, tilapia, and soy tempeh flour. According to Yarnpakdee et al. (2014), Nile tilapia contains essential amino acids such as histidine, isoleucine, threonine, methionine, leucine, phenylalanine, and lysine. Non-essential amino acids of tilapia were alanine, aspartic acid, glutamic acid, and serine - also, the conditional amino acids such as arginine, glycine, and tyrosine. Tempe contains amino acids histidine, serine, arginine, glycine, aspartate, glutamate, threonine, alanine, proline, lysine, tyrosine, methionine, valine, isoleucine, leucine, and phenylalanine (Syida et al., 2018). All these amino acids play a role in the formation of the amino acids in Koya.

Essential amino acids that could be found in Koya consisted of eight types; one of them was histidine. However, in this study, histidine was detected together with one of the non-essential amino acids, serine. Histidine and serine in Koya NT3 were higher than in commercial Koya with $3.61 \%$ and $1.14 \%$, respectively. Both Koya contains histidine because the primary raw materials, tilapia and tempeh flour in NT3 Koya and shrimp in commercial Koya also contain histidine (Yarnpakdee et al., 2014; Priyadarshini et al., 2015; Syida et al., 2018).

\section{Conclusion}

The combination of Nile tilapia-soy flour (NS) and Nile tilapia-tempeh (NT) had a significant effect on the chemical and organoleptic of Koya. Koya NS3 (tilapia : soy flour $=60 \%: 40 \%$ ) and NT3 (tilapia : tempeh flour $=60 \%: 40 \%$ ) were the most preferred by the panelists. 
Koya NS3 contained moisture, ash, fat, protein, and carbohydrates of $13.06 \%, 5.15 \%, 19.59 \%, 54.19 \%$, and $21.50 \%$; respectively while NT3 contained moisture, ash, fat, protein, and carbohydrates of $13.32 \%, 3.89 \%$, $19.28 \%, 48.72 \%$, and $28.06 \%$; respectively. Koya NS3 and NT3 contained linoleic and linolenic fatty acids and higher essential and non-essential amino acids than commercial Koya.

\section{Conflict of interest}

The authors declare no conflict of interest.

\section{Acknowledgments}

This research was funded by Universitas Sebelas Maret (Grant No. 516/UN27.21/PP/2019).

\section{References}

An, K., Zhao, D., Wang, Z., Wu, J., Xu, Y. and Xiao, G. (2015). Comparison of different drying methods on Chinese ginger (Zingiber officinale Roscoe): Changes in volatiles, chemical profile, antioxidant properties, and microstructure. Food Chemistry, 197 (Part B), 1292 - 1300. https://doi.org/10.1016/ j.foodchem.2015.11.033

Anandito, R.B.K., Siswanti, Saputro, R.E. and Purnamayati, L. (2019). Sensory and chemical characteristics of koya made from Snakehead fish (Channa striata) and soybean flour (Glysine max). IOP Conference Series: Earth and Environmental Science, 246(1) $012037 . \quad \mathrm{https}: / /$ doi.org/10.1088/1755-1315/246/1/012037

AOAC. (2005). Official Methods of Analysis the Association of Official Analytical Chemist, p. $185-$ 189. Washington DC: AOAC.

Azevedo, W.M., de Oliveira, L.F.R., Alcântara, M.A., de Magalhães Cordeiro, A.M.T., da Silva Chaves Damasceno, K.S.F., de Araújo, N.K., de Assis, C.F. and de Sousa, F.C. (2020). Physicochemical characterization, fatty acid profile, antioxidant activity and antibacterial potential of cacay oil, coconut oil and cacay butter. PLOS ONE, 15(4), 111. https://doi.org/10.1371/journal.pone.0232224

Bavia, A.C.F., da Silva, C.E., Ferreira, M.P., Leite, R.S., Mandarino, J.M. and Carrao-Panizzi, M.C. (2012). Chemical composition of tempeh from soybean cultivars specially developed for human consumption. Ciencia a Tecnologia de Alimentos, 32 (3), 613-620. https://doi.org/10.1590/S010120612012005000085

Bujang, A. and Taib, N.A. (2014). Changes on amino acids content in soybean, garbanzo bean and groundnut during pre-treatments and tempe making. Sains Malaysiana, 43(4), 551-557.

Chambo, A.P.S., Souza, M.L.R.de, Oliveira, E.R.N.de, Mikcha, J.M.G., Marques, D.R., Maistrovicz, F.C., Visentainer, J.V. and Goes, E.S.D.R. (2017). Roll enriched with Nile tilapia meal: sensory, nutritional, technological and microbiological characteristics. Food Science and Technology, 38(4), 726-732. https://doi.org/10.1590/1678-457x.15317

Chen, C., Sun, B., Li, X., Li, P., Guan, W., Bi, Y. and Pan, Q. (2013). N-3 essential fatty acids in Nile tilapia, Oreochromis niloticus: Quantification of optimum requirement of dietary linolenic acid in juvenile fish. Aquaculture, 416-417(2018), 99-104. https://doi.org/10.1016/j.aquaculture.2013.09.003.

Chukeatirote, E., Eungwanichayapant, P. and Kanghae, A. (2017). Determination of volatile components in fermented soybean prepared by a co-culture of Bacillus subtilis and Rhizopus oligosporus. Food Research, 1(6), 225-233. https://doi.org/10.26656/ fr.2017.6.066

Cortez Netto, J.D.P., Oliveira Filho, P.R.C., LapaGuimaraes, J. and Viegas, E.M.M. (2014). Physicochemical and sensory characteristics of snack made with minced Nile tilapia. Food Science and Technology, 34(3), 591-596. https:// doi.org/10.1590/1678-457x.6395

Damodaran, S. and Arora, A. (2013). Off-flavor precursors in soy protein isolate and novel strategies for their removal. Annual Review of Food Science and Technology, 4, 327-346. https://doi.org/10.1146/ annurev-food-030212-182650

Desta, D., Zello, G.A., Alemayehu, F., Estfanos, T., Zatti, K. and Drew, M. (2019). Proximate analysis of nile tilapia, (Oreochromis niloticus), fish fillet harvested from farmers pond and lake Hawassa, Southern Ethiopia. International Journal for Research and Development in Technology, 11(1), 94 $-99$.

Farzana, T. and Mohajan, S. (2015). Effect of incorporation of soy flour to wheat flour on nutritional and sensory quality of biscuits fortified with mushroom. Food Science and Nutrition, 3(5), 363-369. https://doi.org/10.1002/fsn3.228

Gunawan-Puteri, M.D.P.T., Hassanein, T.R., Prabawati, E.K., Wijaya, C.H. and Mutukumira, A.N. (2015). Sensory Characteristics of Seasoning Powders from Overripe Tempeh, a Solid State Fermented Soybean. Procedia Chemistry, 14, 263-269. https:// doi.org/10.1016/j.proche.2015.03.037.

Huda, N., Fatma, Y., Fazillah, A. and Adzitey, F. (2012). Chemical composition, colour and sensory 
characteristics of commercial serunding (shredded meat) in Malaysia. Pakistan Journal of Nutrition, 11 (1), 1-4. https://doi.org/10.3923/pjn.2012.1.4

Indonesian Statistics. (2017). Production of Aquaculture by Main Commodity (Tons), 2017. Retrieved from Badan Pusat Statistik: https://www.bps.go.id/ indicator/56/1513/1/produksi-perikanan-budidayamenurut-komoditas-utama.html.

Jelen, H., Majcher, M., Ginja, A. and Kuligowski, M. (2013). Determination of compounds responsible for tempeh aroma. Food Chemistry, 141(1), 459-465. https://doi.org/10.1016/j.foodchem.2013.03.047

Kanghae, A., Eungwanichayapant, P.D. and Chukeatirote, E. (2017). Fatty acid profiles of fermented soybean prepared by Bacillus subtilis and Rhizopus oligosporus. Environmental and Experimental Biology, 15, 173-176. https:// doi.org/10.22364/eeb.15.16

Kustyawati, M.E., Nawansih, O. and Nurdjanah, S. (2017). Profile of aroma compounds and acceptability of modified tempeh. International Food Research Journal, 24(2), 734-740.

Lima, D.P., Fuzinatto, M.M., Andretto, A.P., Braccini, G.L., Mori, R.H., Canan, C., de Mendonca, A.N.T., de Oliveira, C.A.L., Pereira, R.R. and Vargas, L. (2015). Mechanically separated fillet and meat nuggets of Nile tilapia treated with homeopathic product. African Journal of Pharmacy and Pharmacology, 9(6), 182-189. https:// doi.org/10.5897/AJPP2014

Marangoni, F., Agostoni, C., Borghi, C., Catapano, A.L., Cena, H., Ghiselli, A., La Vecchia, C., Lercker, G., Manzato, E., Pirillo, A., Riccardi, G., Risé, P., Visioli, F. and Poli, A. (2020). Dietary linoleic acid and human health: Focus on cardiovascular and cardiometabolic effects. Atherosclerosis, 292, 90-98. https://doi.org/10.1016/j.atherosclerosis.2019.11.018

Messina, M. (2016). Soy and health update: evaluation of the clinical and epidemiologic literature. Nutrients, 8, 754. https://doi.org/10.3390/nu8120754

Navarro, R.D., Navarro, F.K.S.P., Filho, O.P.R., Ferreira, W.M., Pereira, M.M. and Filho, J.T.S. (2012). Quality of polyunsaturated fatty acids in Nile tilapias (Oreochromis niloticus) fed with vitamin E supplementation. Food Chemistry, 134(1), 215-218. https://doi.org/10.1016/j.foodchem.2012.02.097

Nguyen, T.T., Le, T.Q. and Songsermpong, S. (2013). Shrimp cassava cracker puffed by microwave technique: effect of moisture and oil content on some physical characteristics. Kasetsart Journal (Natural Science), 47, 434-446.

Pratama, R.I., Rostini, I. and Lviawaty, E. (2018).
Volatile components of raw Patin Catfish (Pangasius hypophthalmus) and Nile Tilapia (Oreochromis niloticus). In IOP Conference Series: Earth and Environmental Science, 176, 012040. https:// doi.org/10.1088/1755-1315/176/1/012040

Priyadarshini, R.S.S., Karuppasamy, P.K., Santhanam, P. and Ramamoorthy, N. (2015). Nutritional composition of penaeidean shrimps along Tamil Nadu, southeast coast of India. Journal of the Marine Biological Association of India, 57(2), 4651. https://doi.org/10.6024/jmbai.2015.57.2.1869-07

Rannou, C., Laroque, D., Renault, E., Prost, C. and Sérot, T. (2016). Mitigation strategies of acrylamide, furans, heterocyclic amines and browning during the Maillard reaction in foods. Food Research International, 90, 154-176. https://doi.org/10.1016/ j.foodres.2016.10.037

Ravi, R., Taheri, A., Khandekar, D. and Millas, R. (2019). Rapid profilling of soybean aromatic compounds using electronic nose. Biosensors, 9(66), 1-13. https://doi.org/10.3390/bios9020066

Regina, M., Affandi, D.R. and Riyadi, N.H. (2012). The study of koya fish characteristics using fish and soy bean (Glycine max) as a suplemental food. Jurnal Teknosains Pangan, 1(1), 28-31.

Saini, R.K. and Keum, Y. (2018). Omega-3 and omega-6 polyunsaturated fatty acids: Dietary sources, metabolism, and significance - A review. Life Sciences, 203, 255-267. https://doi.org/10.1016/ j.lfs.2018.04.049

Sharma, D., Gupta, R. and Joshi, I. (2014). Nutrient analysis of raw and processed soybean and development of value added soybean noodles. Inventi Rapid: Life Style, 2014(1), 1-5.

Shah, N.D. and Limketkai, B.N. (2017). The use of medium-chain triglyserides in gastrointestinal disorders. Nutrition Issues in Gastroenterology, 160, $20-28$.

Sulistiyo, B. (2017). Indonesia Marine and Fisheries Book. Indonesia: Archivelago Indonesia Marine Library.

Syida, W.S.W.K., Noriham, A., Normah, I. and Mohd Yusuf, M. (2018). Changes in chemical composition and amino acid content of soy protein isolate (SPI) from tempeh. International Food Research Journal, 25(4), 1528-1533.

Uauy, R., Kurpad, A., Tano-Debrah, K., Otoo, G.E., Aaron, G.A., Toride, Y. and Ghosh, S. (2015). Role of protein and amino acids in infant and young child nutrition: Protein and amino acid needs and relationship with child growth. Journal of Nutritional Science and Vitaminology, 61, S192- 
S194. https://doi.org/10.3177/jnsv.61.S192

Uwem, U.M., Babafemi, A.A. and Sunday, D.M. (2017). Proximate composition, phytoconstituents and mineral contents of soybean (Glycine Max) flour grown and processed in Northern Nigeria. Advanced in Applied Sciences, 2(4), 48-53. https:// doi.org/10.11648/j.aas.20170204.12

Yarnpakdee, S., Benjakul, S., Kristinsson, H.G. and Kishimura, H. (2014). Antioxidant and sensory properties of protein hydrolysate derived from Nile tilapia (Oreochromis niloticus) by one- and two-step hydrolysis. Journal of Food Science and Technology, 52, 3336-3349. https://doi.org/10.1007/ s13197-014-1394-7

Yulianti, L.E., Sholichah, E. and Indrianti, N. (2019). Addition of tempeh flour as a protein source in mixed flour (mocaf, rice and corn) for pasta product. In IOP Conference Series: Earth and Environmental Science, 251, 012037. https://doi.org/10.1088/17551315/251/1/012037

Zhang, T., Li, J., Ding, Z. and Fan, L. (2015). Effects of initial moisture content on the oil absorption behavior of potato chips during frying process. Food Bioprocess Technology, 9, 331-340. https:// doi.org/10.1007/s11947-015-1625-6 